\title{
Workshops for approaching suicidal behavior: implementation in Primary Health Care
}

\author{
Oficinas para abordagem ao comportamento suicida: implementação na Atenção Primária à Saúde \\ Formación para el comportamiento suicida: implementación en Atención Primaria de Salud
}

'Universidade Estadual Paulista "Júlio de Mesquita Filho". Botucatu, São Paulo, Brazil.

"Universidade Federal de São Paulo. São Paulo, São Paulo,

Brazil.

How to cite this article:

Santos DCR, Alencar RA, Domingos TS. Workshops for approaching suicidal behavior: implementation in Primary Health Care. Rev Bras Enferm. 2021;74(Suppl 3):e20200405 https://doi.org/10.1590/0034-7167-2020-0405

Corresponding author:

Daniele Cristina Ribeiro dos Santos

E-mail: ribeiro_82@hotmail.com

EDITOR IN CHIEF: Dulce Barbosa

ASSOCIATE EDITOR: Fátima Helena Espírito Santo

Submission: $07-08-2020$

Approval: $10-31-2020$

\begin{abstract}
Objective: to describe the implementation of workshops on the approach of people in psychological distress with suicidal behavior for Primary Health Care workers and managers. Methods: this is an action research developed for Primary Health Care professionals in a city in the countryside of São Paulo. Charles Maguerez's Arch methodology was used as a theoretical framework to construct the workshops. Results: through active strategies and the exercise of reflection-action, the workshops enabled participants to raise awareness on the topic, articulation between professionals and managers, and the co-responsibility required to care for users with suicidal behavior assisted in Primary Health Care. Final considerations: the workshops broadened knowledge, facilitating skill development to qualify Primary Health Care professionals in caring for people with suicidal behavior.

Descriptors: Suicide; Suicide, Attempted; Primary Health Care; Health Human Resource Training; Problem-Based Learning.
\end{abstract}

\section{RESUMO}

Objetivo: descrever a implementação de oficinas sobre a abordagem da pessoa em sofrimento psíquico com comportamento suicida para os trabalhadores e gestores da Atenção Primária à Saúde. Métodos: trata-se de uma pesquisa-ação desenvolvida para profissionais da Atenção Primária à Saúde de um município do interior de São Paulo. Utilizou-se a metodologia do Arco de Maguerez como referencial teórico para construção das oficinas. Resultados: por meio das estratégias ativas e do exercício da reflexão-ação, as oficinas possibilitaram aos participantes a sensibilização sobre o tema, a articulação entre profissionais e gestores e a corresponsabilidade requeridas para o cuidado do usuário com comportamento suicida atendido na Atenção Primária à Saúde. Considerações finais: as oficinas ampliaram o conhecimento, facilitando o desenvolvimento de habilidades para qualificação dos profissionais da Atenção Primária à Saúde no cuidado à pessoa com comportamento suicida.

Descritores: Suicídio; Tentativa de Suicídio; Atenção Primária à Saúde; Capacitação de Recursos Humanos em Saúde; Aprendizagem Baseada em Problemas.

\section{RESUMEN}

Objetivo: describir la implementación de talleres sobre el abordaje de la persona en distrés psicológico con conducta suicida para trabajadores y gestores de Atención Primaria de Salud. Métodos: esta es una investigación-acción desarrollada para profesionales de Atención Primaria de Salud en un municipio del interior de São Paulo. Se utilizó la metodología Arco de Maguerez como marco teórico para la construcción de los talleres. Resultados: a través de estrategias activas y el ejercicio de reflexión-acción, los talleres permitieron a los participantes sensibilizar sobre el tema, la articulación entre profesionales y gestores y la corresponsabilidad requerida para la atención de los usuarios con conducta suicida atendidos en la Atención Primaria de Salud. Consideraciones finales: los talleres ampliaron conocimientos, facilitando el desarrollo de habilidades para capacitar a los profesionales de la Atención Primaria de Salud en el cuidado de personas con conducta suicida.

Descriptores: Suicidio; Intento de Suicidio; Atención Primaria de Salud; Capacitación de Recursos Humanos en Salud; Aprendizaje Basado en Problemas. 


\section{INTRODUCTION}

The importance of integrating mental health care into Primary Health Care (PHC) services has been defended since the 1970s through discussions triggered by the World Health Organization to signatory countries ${ }^{(1)}$. In Brazil, from this time frame, two main movements, the Sanitary Reform and the Psychiatric Reform, have enabled advances in the construction of a network of territorial and community-based services to meet population's health needs ${ }^{(2)}$.

In this context, suicidal behavior has been a challenge for professionals working in PHC services. It is indicated that a significant portion of the people who committed or attempted suicide utilized these services a few months before their occurrence. Data from France and the United States show that $80 \%$ of people with depressive symptoms are treated in $\mathrm{PHC}$, which represents $20 \%$ of the total number of visits ${ }^{(3-6)}$.

Despite the different definitions, suicidal behavior conforms to a continuum: threats, self-harm, frustrations, hopelessness, social flight, depression, thoughts of self-destruction, suicide attempts, and suicide itself $f^{(7-8)}$. Considering this behavior, actions aimed at its prevention and detection are possible to be offered by $\mathrm{PHC}$ health professionals, and among the challenges for its operationalization, training strategies have been the object of investigation.

In Brazil, PHC has in Family Health Strategy (FHS) the priority bet for reversing the health care model in the Unified Health System (SUS - Sistema Único de Saúde). To care for people with suicidal behavior and as Psychosocial Care Network (RAPS - Rede de Atenção Psicossocial) equipment, longitudinal, comprehensive, universal and equitable care for mild cases is expected, exercising welcoming, qualified listening and care for mild cases. With regard to moderate and severe cases, $\mathrm{PHC}$ is proposed, through the coordination and ordering of care, establish the articulation of moderate and severe cases with other RAPS equipment ${ }^{(9-10)}$.

Several training formats have been used to train professionals and students distributed in generalist or specialized services, aiming to increase their knowledge, skills, and attitudes. Among the studies, it is observed that higher levels of knowledge and confidence by health professionals favor the attitudinal dimension around the management of users with suicidal behavior. Although medicine and nursing are the most investigated professions, different results are not identified in the assessment of training in relation to professionals' attitudes about suicidal behavior according to professional categories or specialties ${ }^{(11-13)}$.

In certain parts of the world, suicide is still considered a legal offense. It seeks to raise the influence of cultural, political and social factors on professionals' attitudes. Among these, religion acts positively or negatively depending on the geographic region. Studies carried out in the West tend to identify favorable attitudes in professionals who declare religious habits and the opposite result is observed in studies developed in countries in the East ${ }^{(12-14)}$. Likewise, professionals' accurate interpretation of suicidal speech and behavior, access to specialized services, articulation between the professional nuclei and assistance to professionals in resolving ethical dilemmas remain as gaps ${ }^{(6,11-12)}$.

Based on this bibliographic basis, there is a challenge of great magnitude: training health professionals in $\mathrm{PHC}$ competent to respond to suicidal behavior from the perspective of psychosocial care, through active teaching-learning strategies.

\section{OBJECTIVE}

To describe the implementation of workshops on the approach of people in psychological distress with suicidal behavior for Primary Health Care workers and managers.

\section{METHODS}

\section{Ethical aspects}

The research integrates the master's thesis entitled Workshop for approaching suicidal behavior: implementation in Primary Health Care $^{(15)}$. It was approved by the Research Ethics Committee of Faculdade de Medicina de Botucatu on April 17, 2019. In accordance with Resolution 466/2012 assumptions ${ }^{(16)}$, all participants signed the Informed Consent Form and their identities were preserved.

\section{Type of study}

This is a qualitative research conducted through the actionresearch framework that corresponds to a methodological and technical strategy that allows structuring a social investigation with greater versatility in the elaboration and execution of the resources applied in the study ${ }^{(17-18)}$. Choosing the methodological framework was guided with respect to the epistemic intentionality around the object of study, and its description was adapted to the Consolidated Criteria for Reporting Qualitative Research items ${ }^{(19)}$. Thus, it sought to conduct practices that would change participants' understanding of the challenges encountered in daily work, focusing on suicidal behavior management in PHC. From this perspective, health professionals and researchers become subjects who, involved in the qualification of professional practice, focus on problem situation analysis and coping strategy construction ${ }^{(17-18)}$.

\section{Methodological procedures}

In the first workshop, a sociodemographic and occupational questionnaire, developed by the authors, was applied to characterize the sample. In order to specify participants' knowledge and behaviors towards the object of study, the Suicide Behavior Attitude Questionnaire - SBAQ was used. It is an instrument with 21 statements followed by a visual analog scale, in which participants graphically indicate their response, which vary between totally disagree and totally agree. Affirmations are grouped into three factors: Feelings towards patients; Ability to deal with situations involving suicidal behavior; Conceptions about the right to suicide. After the statements, participants respond with information about their religious habits, experience in care and family contact with a suicidal patient ${ }^{(20)}$.

At the end of each of the three workshops, assessment formats were applied, developed by the authors and detailed in the results section so that participants, anonymously, could briefly develop the potentialities and weaknesses perceived during the workshop in relation to facilitators' content, organization, and performance, and the methodology used in the workshops. With 
the content coming from assessment formats, word clouds were created using software (Wordle ${ }^{\circ}$ ) and presented to participants in a consecutive workshop.

As a dispersion task, participants were asked to deliver a reflective narrative by email or personally. This strategy made it possible, through registration, to rescue memories and reflections raised by the workshop's learning process, which helps in the process of formation, appropriation of the knowledge learned about their participation, conception and experience at each meeting ${ }^{(21)}$. The narratives were not identified by participants and at the end of the workshops, 78 narratives were collected, distributed among the three workshops, respectively, 40, 30 and eight.

The three workshops were audio recorded and later transcribed in full. Together with the other data collection strategies, it made it possible to rescue the experiences and discussions held with the group of participants and researchers, allowing developing an in-service training strategy.

\section{Research setting and participants}

The research was conducted in a medium-sized municipality in the countryside of São Paulo State, geographically located in the Nova Alta Paulista region and with approximately 33,891 inhabitants. With regard to the Health Care Network, the municipality has a philanthropic hospital, ten FHS units and three Health Care Plans, an Extended Family Health Center team and a Psychosocial Care Center - mode I. It should be noted that the entire population has PHC services coverage.

In order to cover the largest number of professionals, physicians, nurses, nursing assistants and Community Health Workers from all FHS units and the three emergency services were invited to participate in the research. Moreover, Epidemiological Surveillance managers and the PHC coordination were invited, in consideration of the degree of governance. Aligned with the methodological assumptions, the sample was intentionally constituted and allowed to select participants with greater involvement, interest and relevance to the object of study ${ }^{(17)}$.

Health professionals, working in some PHC service and committing to participate in the three workshops proposed by signing a Term of Commitment were included. Absence in two of the three workshops was the sole exclusion criterion. Furthermore, participation in the workshops was offered, regardless of the inclusion in the research sample; however, there were no occurrences of this request nor refusals or exclusions.

Initially, the participation of 43 professionals was planned; however, there was greater adherence of workers to the workshops. The final sample totaling 53 participants and included the $\mathrm{PHC}$ coordination, the direction of FHS and the nursing service, the nurse responsible for the center regulation of vacancies and resident professionals of a Multidisciplinary Residency Program in Collective Health and Primary Care, offered by a higher education institution and whose practice settings have $\mathrm{PHC}$ services.

To operationalize the workshops, the 53 participants were divided into two groups distributed in morning and afternoon groups. The workshop was conducted by the three researchers in the present study. Concerning the relationship between the research team and participants, it is worth mentioning that one of the team's researchers is part of the municipality's RAPS, which allowed for a closer relationship with context and with participants; a second researcher, external to the context, but with a previous approach due to a given training; a third researcher had no approximation with the context and with participants.

\section{Theoretical framework}

The theoretical framework of problematization based on Charles Maguerez's Arch was used to organize the workshops, which consists of five stages: observation of reality, key points, theorization, hypotheses of solution and application to reality ${ }^{(22)}$. The choice of this pedagogical strategy occurred due to its alignment with the problematization, facilitating the construction of a workshop directed to the needs identified in the reality of participants' work and the constitution of an educational space for reflection on the action and theoretical-practical integration in professional practice. The intervention-action operationalizing the five stages of Charles Maguerez's Arch was distributed in three meetings held, on a fortnightly basis, between August and September 2019.

\section{RESULTS}

\section{Characterization of participants}

Women figured prominently in the sample (84.9\%), with a mean age of 34 years, ranging between 23 and 57 years; $60.4 \%$ reported having children and $50.9 \%$ declared to be married. With regard to profession, there was participation of Community Health Workers (37.04\%), nurses (25.94\%), physical therapists (9.26\%), physicians (7.41\%), nursing assistants (5.55\%), coordination and direction (5.55\%), nutritionists (5.55\%), a social worker $(1.85 \%)$, and a psychologist (1.85\%). Concerning education, $75 \%$ had higher education and, of these, $37.8 \%$ stated that their graduate program is ongoing or completed. Training time ranged from six months to 34 years, with an average of five years and six months. The average time of work in PHC was three years, with a minimum of three months and a maximum of 18 years. The length of experience in the same coverage area ranged from three months to 18 years, with an average of 24 months.

About mental health training, $44.4 \%$ of the sample reported previous participation in lectures and training. A similar portion (42.6\%) underwent some training addressing the theme of suicide and $44.4 \%$ reported previous contact with users with suicidal behavior. However, a minimum number of participants $(7.7 \%)$ stated that they were in contact with the compulsory notification self-injury form.

\section{First workshop: the discovery of a common problem}

The objective of the first workshop represented yet another opportunity to deepen the observation of reality and identification of key points, which corresponds to the first and second stages of Charles Maguerez's Arch, respectively. As this is the first meeting between participants and the research team, it started with presentation between researchers and participants, contextualizing the research, reading and signing a participation 
consent, sociodemographic and occupational questionnaire, and the Suicide Behavior Attitude Questionnaire application ${ }^{(20)}$. Then, a social contract was drawn up collectively with agreements on workshop dynamics, schedules and behaviors, being kept exposed in the two subsequent workshops.

In order to trigger discussion on suicidal behavior in $\mathrm{PHC}$ in the first activity, a problem situation was processed in small groups. To reflect the reality experienced by participants in the territory, a problem situation was prepared in advance based on medical records from FHS units, identified by means of Compulsory Notification Sheets. This process resulted in the construction of a case of a hypothetical over-user of health units, who had unspecific somatic complaints, weaknesses in family dynamics and culminating in a suicide attempt due to exogenous intoxication.

This activity aimed to access participants' unique conceptions about caring for people with suicidal behavior in $\mathrm{PHC}$, as well as the main challenges to deal with demand. In order to increase participation, three small groups were created to meet the logic of the diversity of professions and health units, with an average of nine participants and a facilitator-researcher. The small group's work was uniformly planned, and the researcher was responsible for facilitating the discussion, having as guidelines the questions: why does a person resort to suicide attempt? From participants' perspectives, who are most exposed to suicide attempts, who commit more suicide attempts in the municipality, what services should assist suicide attempts and what can they do considering prevention and care? Among the participants in the small group, a secretary was elected to record the processing synthesis and a rapporteur to present the group's work in the next activity.

The result of the small group's work was presented in a plenary session. After the three shares, one of the researchers performed a debriefing ${ }^{(23-24)}$. The strategy made it possible to align the diverse knowledge derived from the contribution of small groups around a common problem, deepening participants' understanding and at the same time serving a collective process of validation and reflection on practice.

The fourth activity allowed participants to have greater criticism about the magnitude of suicidal behavior in the municipality so that they could elaborate on other key points. It was previously prepared from a qualitative and quantitative survey and data analysis on suicide and suicide attempts recorded in Compulsory Notification Sheets, between January 2016 and June 2019. The strategy made it possible, through a collective discussion, to recognize suicidal behavior as a local and common reality between each participant and each health unit, leading them to reflect on the limitations of underreporting suicidal behavior and suicide, as well as implications for health work management.

At the end of the period, the first assessment format was applied, with five triggers to be filled in: I met..., I built..., I thought..., I felt... At today's meeting... The formats were collected after completion and first narrative elaboration was requested, with delivery agreed at a later meeting.

\section{Second workshop: rediscovering teamwork}

The first activity was developed from word cloud presentation with the content of the assessments made in the previous workshop, rescuing the main key points elaborated by participants. Then, the result of the Suicide Behavior Attitude Questionnaire ${ }^{(20)}$ was also presented, showing the group's behavior among statements and factors proposed by the instrument. Before starting the second activity, the reflective narratives were collected.

Individually, participants were invited to reflect on three personal skills they had and recognized as necessary for suicidal behavior management, and to write them down on three colored cards that were previously distributed. Afterwards, participants were distributed in small groups, with the same guidelines described in the first workshop, to share and explain their conceptions about the importance of the selected skills to assist people in PHC with suicidal behavior. With the facilitator's support, the articulation between the different skills was discussed, raising awareness of participants to teamwork.

The organization of small groups was maintained and roleplaying planning began ${ }^{(25)}$, which focused on care provided by a health professional and a user in psychological distress. Each of the three groups received different slogans: (G1) planning a health professional character; (G2) planning a user character in psychological distress; (G3) service observers. It is important to note that the groups were unable to exchange information about the actions developed during the construction of the characters, and were supported by the facilitators.

The consecutive activity was the role-playing stage ${ }^{(25)}$. To that end, participants were all arranged in the same room, and participants observing the activity were distributed in different places to have visual access to the scene. After dramatization started, the facilitators acted identifying attitudes, observing performance and controlling time. After five minutes of simulated care, the scene was frozen and the characters, health professionals and users in psychological distress, were able to receive help from the respective groups for the same amount of time. The action was resumed and ended, totaling 15 minutes of action.

After dramatization, there was a group discussion led by debriefing ${ }^{(23-24)}$, which enabled reflection on the action, reflecting the work processes in PHC services in interface with participants' unique perspectives. This process resulted in the collective construction of objectives and turgid changes of meaning for professionals.

At the end, the second assessment format that had three trigger phrases to be filled in: How good... What a pity... How about if... The formats were collected after filling in and the second narrative was requested to be prepared.

\section{Third workshop: discovering networking}

Starting from the presentation of the assessment carried out by participants about the previous workshop and the second narrative collection, printed or digitalized, totaled 30 narratives. For developing network work as a hypothesis of solution in the framework of problematization, a RAPS diagnostic matrix ${ }^{(26)}$ was delivered to each participant, making it possible to know the services that constitute it and what services are present in the municipality.

After clarification of doubts, there was a presentation of the geographic map of the municipality, in which FHS units, RAPS services and intersectoral services were distributed. In each PHC unit, a table was posted showing the personal skills chosen by participants in the previous workshop. 
This activity aimed to develop participants' critical-reflective thinking, leading them to constitute themselves as network agents, i.e., that they are the network itself, because the more they know about the network, the better they will constitute care. This objective was developed concretely using a map and colored lines fixed as participants identified services that could be partners in interventions offered by Family Health teams. It was argued, metaphorically, that the Health Care Network becomes more strengthened as the lines intertwine, interconnecting services: weaving a fine weft network. Figure 1 illustrates the conformations before (on the left) and after discussion (on the right).
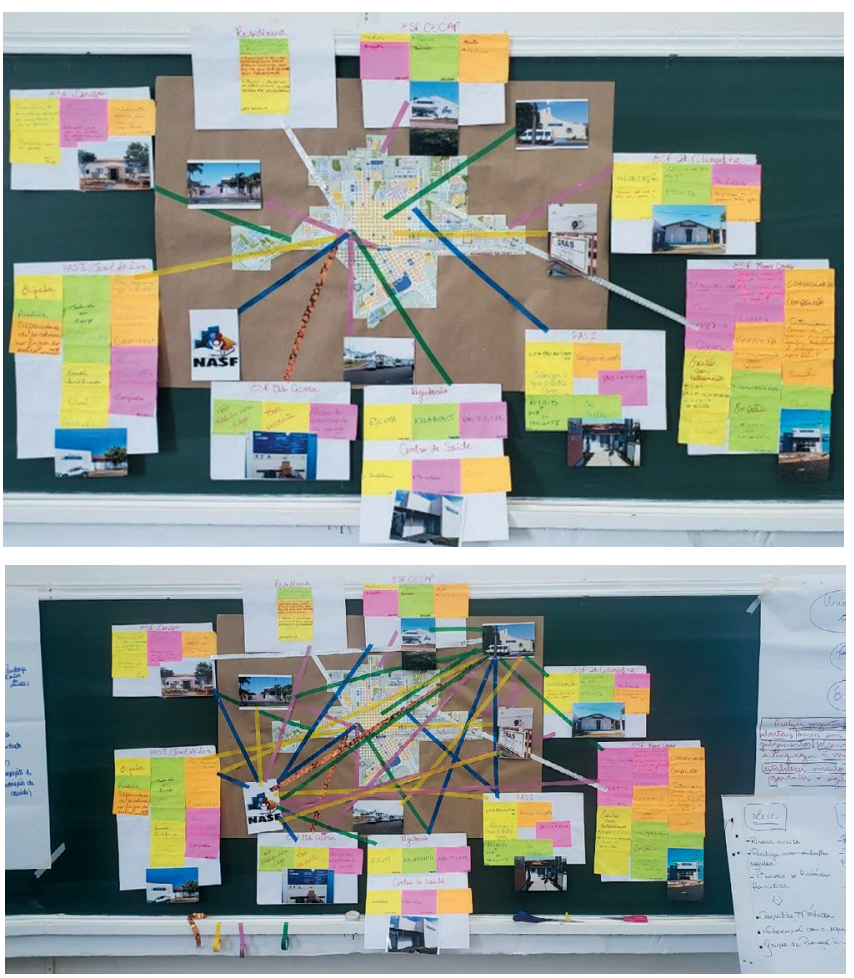

Figure 1 - Care network constitution for people with suicidal behavior in Primary Health Care. Adamantina, São Paulo, Brazil, 2020

Participants were then divided into three small groups for the workshop's third activity, which consisted of developing a propositional flowchart for assisting people under psychological distress and suicidal behavior in line with the municipality. In plenary, each group presented its flowchart through debriefing, and, based on the presentations, a collective synthesis was carried out articulating future agreements to qualify the approach to people with suicidal behavior through networking.

Finally, the second application of the Suicide Behavior Attitude Questionnaire ${ }^{(20)}$ was carried out in order to identify changes after the three workshops. The last assessment format was applied, which contained a triggering question: what contributions from today's workshop do I take to work? Delivery of the last narrative was requested, agreeing to deliver it online or in print, considering that one of the researchers resided in the municipality.

\section{DISCUSSION}

The main result of this action research comprised a training strategy operationalization for $\mathrm{PHC}$ professionals, along the lines of workshops, aligned with the assumptions of active learning methodologies, offering participants experiences to reconfigure care practices and processes through reflection-action with pedagogical tools such as group dynamics and narratives.

Through the findings identified in an integrative literature review, it is possible to observe the alignment of this investigation with the other researches that take professional training as the object of study. There is a convergence of studies being outlined qualitatively through participatory designs and action research, involving as participants, primarily, health professionals, followed by residents of multidisciplinary programs and undergraduate students ${ }^{(27)}$.

There is consensus in scientific literature on theoretical and practical weaknesses in the training in health professionals mental health ${ }^{(28-30)}$, a situation explained in part by the historical development of health courses under the biomedical hegemony and, substantially, due to the deconstruction of asylum practices as a result of the Psychiatric Reform, based on deinstitutionalization $^{(2,31)}$. This context argues in favor of continuing education of health professionals operated in the same manner proposed by the results of this research ${ }^{(32)}$.

In this regard, the importance of frequent development of training workshops is emphasized in order to train and raise awareness in PHC professionals, especially in smaller municipalities that do not have all the devices that make up RAPS. It points to the urgent need for PHC teams to be technically prepared to respond to the health needs of people under psychological distress and suicidal behavior to act in prevention, early detection, and assistance ${ }^{(9-10,33)}$.

The differential of this action research is identified in the articulation of two strategies: work in small groups and narratives as a pedagogical device. Both represent the dyad that acts in the affective and professional dimensions, pillars of learning, when developing group awareness and professional identity ${ }^{(27)}$. The group experiences, operationalized by this investigation in the processing of problem situations, role-playing and reflective exhibitions, are in line with the group dynamics that aim to trigger new behaviors and to recompose health work aimed at interdisciplinarity ${ }^{(27)}$. They were also operated in the paideia method: subjective and social provocative process, in a protected space and mediated by specialized support, aimed at expanding analysis and intervention capacities ${ }^{(27,34)}$.

The potential of using narratives in active teaching-learning processes gains concreteness and importance when they make it possible to recognize the development of subtle skills that are linked to the learning process ${ }^{(27,35)}$. In this direction, the composition of written narratives requested at the end of the workshops represented an opportunity to record the contributions and weaknesses of the training process that crossed health professionals' experience ${ }^{(36)}$. Furthermore, it evidenced reflection-action extending problem situations, cognitive challenges and discussion to a unique space for the elaboration of oneself and professional practices, a potential observed in another investigation that was also operated in the logic of narratives ${ }^{(21,35)}$.

To effect learning processes permeated by the uniqueness of experiences, debriefing represents an educational method, expressly accepted in contexts of realistic simulation, which favors reflection, meaningful learning, synthesis, experience and skill 
development ${ }^{(23-37)}$. Its use in this research, in addition to meeting the benefits previously described, made it possible to implement this method as a tool for the skills of interprofessional practice ${ }^{(38)}$, indicating that the summative stage ${ }^{(23)}$ favored the investigative process for acting as a validation strategy simultaneous to the construction of data in qualitative research ${ }^{(19)}$.

When considering the facilitation of experiential learning to develop skills as one of the benefits promoted by debriefing ${ }^{(23)}$, it is possible to understand the result of the workshops to develop this dimension of competence. In this regard, knowledge and attitude development remained a challenge for the workshops presented in this research.

In turn, the weakness in developing attitudes observed in the workshops of this investigation is partly due to the object of study. It discusses the mobilization of beliefs, cultural and religious values, culturally and distinctly interwoven in health professionals and whose deconstruction requires a complex reconfiguration of their internal structures, directly affecting the availability for care $^{(6,11-14)}$. The scale used before and after the workshops ${ }^{(20)}$ and problem situation processing represented possibilities to understand the concepts that are at stake in caring for people with suicidal behavior.

Attention is paid to the result observed in the third workshops, in which participants unveiled the possible articulations between the municipality's health services and the intersectoral network, building conformations of a Health Care Network strengthened through several lines of agreement. The proposition of this process rescues the necessary construction of innovative, more democratic practices, aligned with institutional interventions ${ }^{(27-35)}$ and with which one can expand the autonomy of health act production ${ }^{(39)}$. It is attributed and indicated the importance of aggregating, in the same training strategy, health care professionals and management ${ }^{(27,35)}$, which, in addition to democratizing the learning process, favors the development of potential agreements and cooperation that aim to effect the lines established in intra and intersectoral logics.

\section{Study limitations}

One limitation refers to the design of this study that did not make it possible to monitor the occurrence of changes in health professionals' performance regarding the approach to people with suicidal behavior in $\mathrm{PHC}$, which corresponds to the stage of applying the reality of Charles Maguerez's Arch.

\section{Contributions to nursing}

The workshops presented in this investigation can be implemented in other realities and, given the loco-regional needs, can be developed together or separately. The study setting corresponds to the reality of a portion of approximately $80 \%$ of Brazilian municipalities, which have less than 35 thousand inhabitants and, therefore, do not meet the population indicators that justify the request for specialized psychosocial care services. In this horizon, intra and intersectoral network represent the main potential for carrying out care practices in line with RAPS assumptions.

\section{FINAL CONSIDERATIONS}

The workshops promoted training and awareness of PHC professionals with regard to psychological distress and suicidal behavior, an essential foundation for qualifying the skills required for care. Concretely, strategies for suicidal behavior management were identified, articulating teamwork and support from the Health Care Network and the intersectoral approach. When envisioning this possibility, participants increased their criticism about the biomedical model and its incompatibility with the health surveillance model. It is argued that the results obtained through the workshops are directly linked to the methodological proposition. In this regard, it is important to highlight the potential of active methodologies in teaching-learning in training strategies for health workers.

\section{REFERENCES}

1. Ministério da Saúde. Secretaria de Atenção à Saúde. DAPE. Coordenação Geral de Saúde Mental. Reforma psiquiátrica e política de saúde mental no Brasil. Documento apresentado à Conferência Regional de Reforma dos Serviços de Saúde Mental: 15 anos depois de Caracas. Brasília (DF): OPAS; 2005.

2. Amarante P, Nunes MO. Psychiatric reform in the SUS and the struggle for a society without asylums. Ciênc Saúde Colet [Internet]. 2018 [cited 2020 Apr 29];23(6):2067-74. https://doi.org/10.1590/1413-81232018236.07082018

3. Carr MJ, Ashcroft DM, Kontopantelis E, Awenat Y, Cooper J, Chew-Graham C, et al. The epidemiology of self-harm in a UK-wide primary care patient cohort, 2001-2013. BMC Psychiatry [Internet]. 2016 [cited 2019 Dec 10];16(1):1-10. https://doi.org/10.1186/s12888-016-0753-5

4. LoParo D, Florez IA, Valentine N, Lamis DA. Associations of suicide prevention trainings with practices and confidence among clinicians at community mental health centers. Suicide Life Threat Behav [Internet]. 2019 [cited 2020 Apr 29];49(4):1148-56. https://doi.org/10.1111/ sltb.12498

5. Oneib B, Sabir M, Otheman Y, Abda N, Ouanass A. Suicidal ideations, plans and attempts in primary care: cross-sectional study of consultants at primary health care system in Morocco. Pan Afr Med J [Internet]. 2016 [cited 2020 Apr 29];24:274. https://doi.org/10.11604/ pamj.2016.24.274.9060

6. Saini P, Chantler K, Kapur N. General practitioners' perspectives on primary care consultations for suicidal patients. Health Soc Care Community [Internet]. 2016 [cited 2020 Apr 29];24(3):260-9. https://doi.org/10.1111/hsc.12198

7. Goodfellow B, Kõlves K, Leo D. Contemporary definitions of suicidal behavior: a systematic literature review. Suicide Life Threat Behav [Internet]. 2019 [cited 2020 Apr 29];49(2):488504. https://doi.org/10.1111/sltb.12457 
8. Klonsky ED, Saffer BY, Bryan CJ. Ideation-to-action theories of suicide: a conceptual and empirical update. Curr Opin Psychol [Internet]. 2018 [cited 2020 Apr 29];22:38-43. https://doi.org/10.1016/j.copsyc.2017.07.020

9. Pessoa DMS, Freitas RJM, Melo JAL, Barreto FA, Melo KCO, Dias ECS. Nursing assistance in primary health care for adolescents with suicidal Ideations. Rev Min Enferm [Internet]. 2020 [cited 2020 Sep 20];24:e-1290. https://doi.org/10.5935/1415-2762.20200019

10. Ferreira ML, Varga MAO, Rodrigues J, Trentin D, Brehmer LCF, Lino MM. [Suicidal Behavior and Primary Health Care: an integrative review]. Enferm foco (Brasília) [Internet]. 2018 [cited 2020 Sep 20]9(4):50-4. https://doi.org/10.21675/2357-707X.2018.v9.n4.1803 Portuguese

11. McDonnell S, Nelson PA, Leonard S, McGale B, Chew-Graham CA, Kapur N, et al. Evaluation of the impact of the PABBS suicide bereavement training on clinicians' knowledge and skills. Crisis [Internet]. 2020 [cited 2020 Apr 29];1-8. https://doi.org/10.1027/0227-5910/a000646

12. Boukouvalas E, El-Den S, Murphy AL, Salvador-Carulla L, O'Reilly CL. Exploring health care professional's knowledge of, attitudes towards, and confidence in caring for people at risk of suicide: a systematic review. Arch Suicide Res [Internet]. 2019 [cited 2020 Apr 23];1-31. https:// doi.org/10.1080/13811118.2019.1586608

13. Song C. Suicide assessment training: the effect on the knowledge, skills, and attitudes of mental health professionals and trainees [Internet]. 2018 [cited 2020 Apr 29];244. Available from: https://digitalcommons.georgefox.edu/psyd/244

14. Osafo J, Akotia CS, Boakye KE, Dickson E. Between moral infraction and existential crisis: exploring physicians and nurses' attitudes to suicide and the suicidal patient in Ghana. Int J Nurs Studies [Internet]. 2018 [cited 2020 Apr 21];85:118-25. https://doi.org/10.1016/j. ijnurstu.2018.05.017

15. Santos DCR. Oficina para abordagem ao comportamento suicida: implementação na Atenção Primária à Saúde [Dissertação] [Internet]. Universidade Estadual Paulista "Júlio de Mesquisa Filho"; 2020 [cited 2021 March 30]. Available from: https://repositorio.unesp.br/ handle/11449/192412

16. Conselho Nacional de Saúde (BR). Resolução no 466 de 12 de Dezembro de 2012. Diretrizes e normas regulamentadoras de pesquisas envolvendo seres humanos [Internet]. 2012[cited 2019 May 20]. Available from: http://www.conselho.saude.gov.br/resolucoes/2012/ Reso466.pdf

17. Thiollent M. Metodologia da pesquisa-ação. 18.ed. São Paulo: Cortez; 2011. 135p.

18. Holloway I, Galvin K. Qualitative research in nursing and healthcare. 4th ed. Chinchester: Wiley-Blacwell; 2016. 368p.

19. Tong A, Sainsbury P, Craig J. Consolidated criteria for reporting qualitative research (COREQ): a 32-item checklist for interviews and focus groups. Int J Qual Health Care [Internet]. 2007 [cited 2020 Apr 21];19(6):349-357. https://doi.org/10.1093/intghc/mzm042

20. Botega NJ, Reginato DG, Silva SV, Cais CFS, Rapeli CB, Mauro MLF, et al. Nursing personnel attitudes towards suicide: the development of a measure scale. Braz J Psychiatry [Internet]. 2005 [cited 2019 Dec 10];27(4):315-8. https://doi.org/10.1590/S1516-44462005000400011

21. Castellanos MEP. The narrative in qualitative research in health. Ciênc Saúde Colet [Internet]. 2014 [cited 2020 Apr 21];19(4):1065-76. https://doi.org/10.1590/1413-81232014194.12052013

22. Prado ML, Velho MB, Espíndola DS, Sobrinho SH, Backes VMS. [Charles Maguerez Arc: reflecting methodology strategies on active training for health professionals]. Esc Anna Nery [Internet]. 2012 [cited 2020 Apr 19];16(1):172-7. https://doi.org/10.1590/S141481452012000100023 Portuguese

23. Goés FSN, Jackman D. Development of an instructor guide tool:'Three Stages of Holistic Debriefing'. Rev Latino-Am Enferm [Internet]. 2020 [cited 2020 Apr 20];28:e3229. https://doi.org/10.1590/1518-8345.3089.3229

24. Lavoie P, Pepin J, Cossette S. Contribution of a reflective debriefing to nursing students' clinical judgment in patient deterioration simulations: a mixed-methods study. Nurse Educ Today [Internet]. 2017 [cited 2020 Apr 20];50:51-6. https://doi.org/10.1016/j. nedt.2016.12.002

25. Rabelo L, Garcia VL. [Role-Play for the Development of Communication Skills]. Rev Bras Educ Med [Internet]. 2015 [cited 2020 Apr 20];39(4):586-96. https://doi.org/10.1590/1981-52712015v39n4e01052014 Portuguese

26. Ministério da Saúde (BR). Conselho Nacional de Saúde. Portaria n. ${ }^{\circ}$ 3588, de 21 de dezembro de 2017. Altera as Portarias de Consolidação no 3 e n 6, de 28 de setembro de 2017, para dispor sobre a Rede de Atenção Psicossocial, e dá outras providências [Internet]. Brasília: Ministério da Saúde; 2017 [cited 2020 Apr 29]. Available from: http://bvsms.saude.gov.br/bvs/saudelegis/gm/2017/prt3588_22_12_2017.html

27. Diniz DS, Sá MC. The use of narratives and group device approach in education/continuing education of health professionals: a literature review. Interface (Botucatu) [Internet]. 2019 [cited 2020 Apr 21];23:e180217. https://doi.org/10.1590/interface.180217

28. Kourgiantakis T, Sewell KM, Lee E, Adamson K, McCormick M, KuehI D, et al. Enhancing social work education in mental health, addictions, and suicide risk assessment: a teaching note. J Soc Work Educ [Internet]. 2019 [cited 2020 Apr 21];1-8. https://doi.org/10.1080/10437797.2 019.1656590

29. Rodrigues J, Lazzarini DD, Martini JG, Testoni AK. Professor's perception of mental health teaching in nursing. Texto Contexto Enferm [Internet]. 2019 [cited 2020 Apr 21];28:e20170012 https://doi.org/10.1590/1980-265x-tce-2017-0012

30. Rodrigues WO, Morão LC, Almeida ACV, Oliveira GS. [Limits of theoretical-pratical mental health education in health professional training]. Rev Port Enferm Saúde Mental [Internet]. 2016 [cited 2020 Apr 21];(spe4):107-14. https://doi.org/10.19131/rpesm.0149 Portuguese

31. Scafuto JCB, Saraceno B, Delgado PGG. [Training and permanent education in mental health under deinstitutionalization's perspective (2003-2015)]. Com Ciências Saúde [Internet]. 2017 [cited 2020 Apr 21];28(3/4):350 8. Available from: http://www.escs.edu.br/revistaccs/ 
index.php/comunicacaoemcienciasdasaude/article/view/277/283 Portuguese

32. Emerich BF, Onocko-Campos R. [Mental Health professional education: reflections based on the conceptions of Subject, Collective and Institution]. Interface (Botucatu) [Internet]. 2019 [cited 2020 Apr 21];23:e170521. https://doi.org/10.1590/interface.170521 Portuguese

33. Silveira CB, Costa LSP, Jorge MSB. [Health Care Networks as producers of mental health care: a reflective analysis]. Rev Port Enferm Saúde Mental [Internet]. 2018 [cited 2020Jan 15];(19):61-70. https://doi.org/10.19131/rpesm.0203 Portuguese

34. Viana MMO, Campos GWS. [Paideia training for matrix support: a pedagogical strategy centered on reflection of practice]. Cad Saúde Pública [Internet]. 2018 [cited 2020 Sep 20];34(8):e00123617. https://doi.org/10.1590/0102-311X00123617 Portuguese.

35. Azevedo CRF, Gomes R. Use of narrative in continuing health education: educational directions, successes and limits. Interface (Botucatu) [Internet]. 2019 [cited 2020 Apr 21];23:e170957. https://doi.org/10.1590/interface.170957

36. Bondía JL. [Notes on experience and the knowledge of experience]. Rev Bras Educ [Internet]. 2002 [cited 2020 Apr 29];(19):20-8. https://doi. org/10.1590/S1413-24782002000100003 Portuguese

37. Gaelly D. In-simulation debriefing increases therapeutic communication skills. Nurse Educ [Internet]. 2019 [cited 2020 Apr 21];44(6):295-9. http://dx.doi.org/10.1097/NNE.0000000000000643

38. Poore J, Dawson J, Dunbar DM, Parrish K. Debriefing Interprofessionally: a tool for recognition and reflection. Nurse Educ [Internet]. 2019 [cited 2020 Apr 21];44(1):25-8. https://doi.org/10.1097/NNE.0000000000000518

39. Merhy EE, Feuerwerker LCM, Santos MLM, Bertussi DC, Baduy RS. Basic Healthcare Network, field of forces and micropolitics: implications for health management and care. Saúde Debate [Internet]. 2019 [cited 2020 Sep 20];43(spe6):70-83. https://doi. org/10.1590/0103-11042019s606 